\title{
8
}

\section{Modeling Green Infrastructure Components in a Combined Sewer Area}

\author{
Robert Pitt and John Voorhees
}

\subsection{Introduction}

The purpose of the project described in this chapter is to evaluate the water quality and quantity improvement benefits of a large scale application of green infrastructure control practice retrofits in an entire monitored subcatchment. These green infrastructure controls have been shown, when implemented and maintained properly, to increase retention at the runoff source. This increased retention decreases the runoff volume entering the drainage system and the demand on a drainage system. Many researchers have reported findings that support these observations for individual or small neighborhood applications at LID (low impact development) conferences. This project is unique in that a large area is being retrofitted and will be monitored for many different scales to measure these benefits. This chapter describes a preliminary modeling effort that is being used to assist in the design of the practices at the site, showing how complementary practices that can be constructed on private property which will enhance the performance of the curb-side biofilters to be constructed in the public right-of-way.

This chapter describes updated modeling results for the use of rain gardens, rain barrels or tanks, and roof disconnections, together with preliminary calculations pertaining to curb cut biofilters. They are being examined for potential application in the Kansas City, Missouri, test area for the control of combined sewer overflows. The initial modeling results using WinSLAMM indicate that the use of bioretention facilities in the test area (which has poor soils with limited infiltration capacities) can be effective in

Pitt, R.E. and J. Voorhees. 2011. "Modeling Green Infrastructure Components in a Combined Sewer Area." Journal of Water Management Modeling R241-08. doi: 10.14796/JWMM.R241-08.

(C) CHI 2011 www.chijournal.org ISSN: 2292-6062 (Formerly in Cognitive Modeling of Urban Water Systems. ISBN: 978-0-9808853-4-7) 
the storage of peak flows during many events, significantly decreasing overflows.

\subsection{Project Description}

Areas having separate stormwater systems and areas with combined sewers can benefit from the added storage provided by bioretention cells, rain gardens or other green infrastructure management practices. This pilot project is part of a larger adaptive management approach to incorporate green solutions into the Kansas City combined sewer overflow (CSO) long term control plan. The project involves local and regional efforts to provide a basis for the success of the implementation of green solution infrastructure and stormwater management at the neighborhood, watershed and regional levels. The project will demonstrate the strategy and methodology, including model support, for identifying where and how green solutions will be implemented within Kansas City.

The overall key project objectives are:

- to demonstrate the integration of green solutions with traditional gray infrastructure in an urban core neighborhood having a combined sewer system;

- to develop a methodology for implementation of green solutions;

- to measure the changes in the peak flow, total volume and pollutant mass of storm events in the receiving system or the reduction of combined wastewater volumes, pollutant loads and overflows;

- to calibrate and verify a model for predicting the qualitative and quantitative outcomes of implementing green solutions; and

- to compare economic costs and benefits of integrated green and gray solutions.

Pre- and post-control installation monitoring of the combined sewer flows in the drainage area below the area where the stormwater management controls are installed are critical activities in this project. The stormwater management controls in the demonstration area drain to the municipal combined sewer drainage system in the Middle Blue River watershed. This drainage pattern will allow isolation of the effects of the upland stormwater controls with minimal flows coming from outside areas. The study area is a 100 acre (39 ha) subcatchment. The selected pilot subwatershed contains commercial, medium density, and some high density residential land uses. 
An adjacent 80 acre (33 ha) subcatchment has been selected as a control watershed.

The watershed model (WinSLAMM) and the sewerage model (SWMM) will be calibrated for this area using pre-construction flow data and water quality data. Both dry and wet weather flow data will be recorded. The calibrated models are being used early in the project to predict the effects of the upland controls, and the accuracy of these predictions will be determined when the controls have been installed. After the models have been calibrated and verified for the demonstration area, they will be used to predict the effects of wider applications of the upland controls across the city. WinSLAMM will be used to calculate the stormwater contributions to the combined sewerage system during wet weather, by providing a time series of flows and water quality conditions, for various types of upland controls. SWMM, with its detailed hydraulic modeling capabilities, will be used to focus on the interaction of the time series data with the sewerage flows and detailed hydraulic conditions in the drainage system.

Controls based on traditional CSO control practices were originally designed for this area. However, several years ago, Kansas City municipal officials, in conjunction with local citizen groups, started to investigate how low impact development concepts could be used in the area instead of the traditional very large storage tanks and tunnels. The city is applying the CSO controls identified in the nine minimum controls list, such as making necessary repairs to the sewerage to minimize infiltration and inflow. The use of bioretention controls has been shown to be promising in meeting the CSO control requirements, at less cost than traditional methods, while also providing needed community benefits. Struck (2009), together with other presenters at the EWRI World Environmental and Water Resources Congress in Kansas City, Missouri, provides overviews of this project.

\subsection{Roof Runoff Harvesting Potential}

The total pervious cover area in the residential land use is 65.1 acres $(26.5$ ha). With 576 homes in this area, each has an average $4,925 \mathrm{ft}^{2}\left(458 \mathrm{~m}^{2}\right)$ pervious area that could potentially be irrigated.

The stormwater harvesting potential for these homes was calculated based on supplemental irrigation requirements for the basic landscaped areas. The basic irrigation needs were determined to be the amount of water needed to satisfy the potential evapotranspiration requirements of typical turf grasses, after subtracting the normal rainfall. The monthly rainfall for the 1973 through 1999 period at the Kansas City airport was examined to determine the irrigation needs for the area. This $27 \mathrm{y}$ unbroken continuous rain 
record indicated an average total annual rainfall of $37.5 \mathrm{in}$. (952.5 mm), with most falling in the spring to early fall. A much smaller fraction of the annual rain occurs from December through February.

Figure 8.1 shows the monthly evapotranspiration (ET) potential of typical turf grasses based on data from the closest long-term ET monitoring station to Kansas City (Ottawa, Kansas, a University of Kansas field station in eastern Kansas, about $50 \mathrm{mi}, 80 \mathrm{~km}$, from the study area). The total annual ET for turf grass is $52 \mathrm{in.} / \mathrm{y}(1320 \mathrm{~mm} / \mathrm{y})$, while the annual total rainfall is 37 in./y $(940 \mathrm{~mm} / \mathrm{y})$, resulting in a rainfall deficit of about $15 \mathrm{in} . / \mathrm{y}(381 \mathrm{~mm} / \mathrm{y})$. Figures 8.2 and 8.3 are plots of the monthly rainfall and of the supplemental irrigation needs to meet this ET respectively. Most of the supplemental irrigation is needed in July and August. There is an excess of rainfall over ET in October through December and therefore no supplemental irrigation is needed during those months.

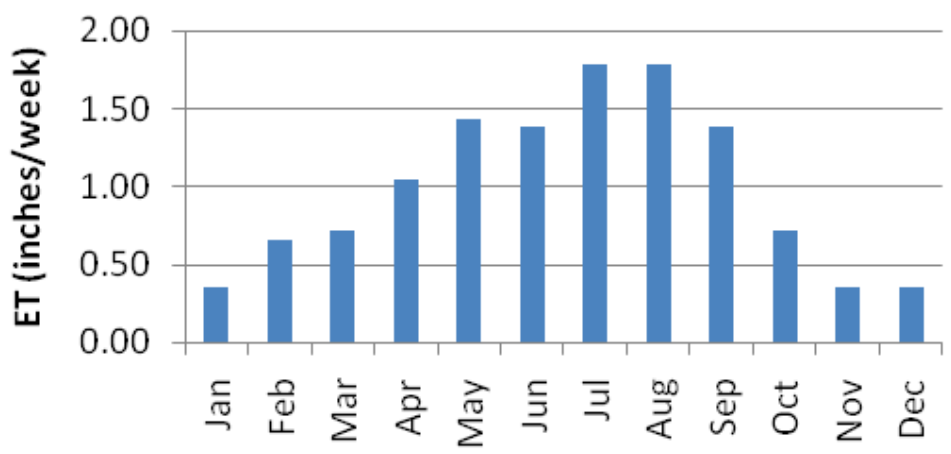

Figure 8.1 Monthly average evapotranspiration at Ottawa, Kansas (ET potential adjusted for typical turf grass).

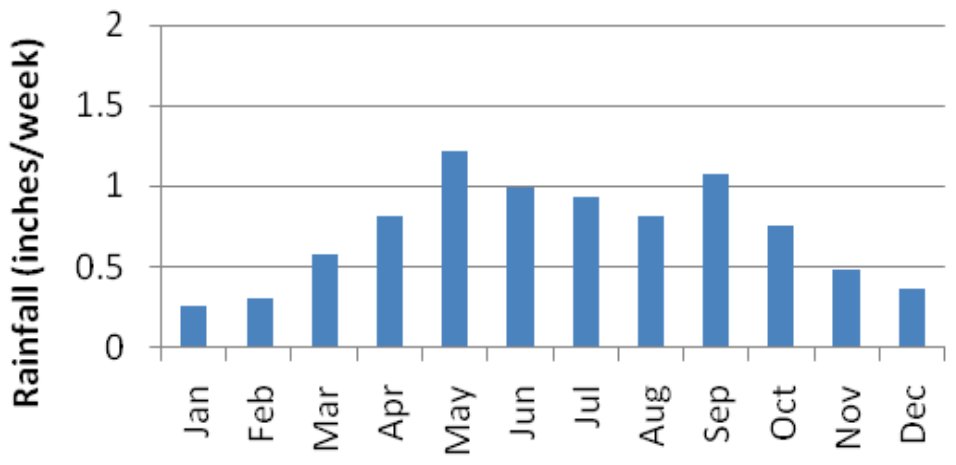

Figure 8.2 Average monthly rainfall at Kansas City (1973-99). 


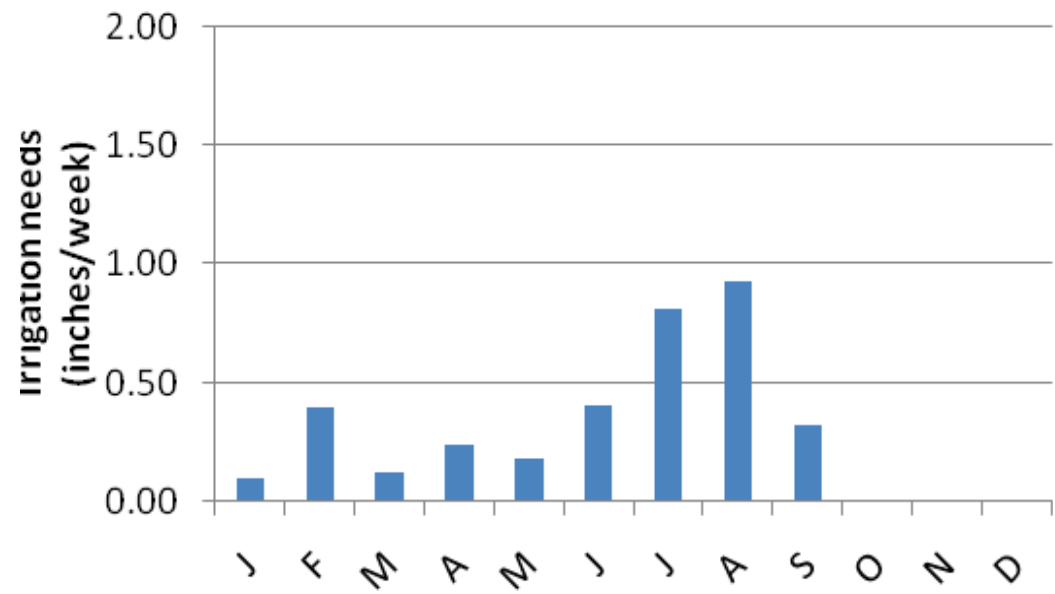

Figure 8.3 Average supplemental irrigation needed to meet ET for typical turfgrass.

The total amount of rainfall harvesting that could be used to match the potential ET is $46600 \mathrm{gal}\left(176 \mathrm{~m}^{3}\right) /$ household/y. With a landscaped area of $4925 \mathrm{ft}^{2}\left(458 \mathrm{~m}^{2}\right) /$ household, the annual irrigation requirement is $15 \mathrm{in}$. (381 $\mathrm{mm})$, or, during the nine months when there is an irrigation need, an average of $0.5 \mathrm{in}$. $(13 \mathrm{~mm}) /$ week. This is a total of $27 \mathrm{MG}\left(102000 \mathrm{~m}^{3}\right) / \mathrm{y}$ for the 100 acre $(40.5 \mathrm{ha})$ project area. Continuous simulations are used to see how much of the captured stormwater can actually be used for different storage scenarios, based on a comparison of the interevent conditions and rain patterns with the water need patterns. It may be possible to use a greater amount of this water for irrigation for certain plants, but that must be further investigated. These irrigation values are for typical turf grasses; theoretically, any additional irrigation would be infiltrated into the soil and not be used by plants. The infiltration rates through the soils at the project site are low, as described in the following section. Research by the USGS (Selbig and Balster, 2010) shows that ET values for typical urban vegetation, calculated using the methods commonly used for agricultural operations, are inaccurate. Therefore, the actual irrigation associated stormwater beneficial use can be much larger than these initial calculations show.

\subsection{WinSLAMM Modeling of Green Infrastructure Controls}

The processes incorporated in WinSLAMM modeling which are of importance in calculating the effects of these controls have been described in several recent monographs from this conference series and other sources 
(Pitt et al., 2008a; Pitt et al., 2008b; Pitt and Clark, 2008). Pitt (1999) reviews the urban hydrology components of WinSLAMM and the processes used in developing the urban hydrological processes, including the monitoring and subsequent calibration of impervious area disconnection benefits.

Rain gardens, water storage tanks and beneficial uses, along with disconnecting roof runoff are some of the options being considered for private property in the residential areas of the Kansas City study area. The rain gardens and storage tanks would be located on private property and receive the runoff from directly connected roofs. Their maximum effect is dependent on the amount of runoff that is contributed from the source areas where they would be located. Table 8.1 shows that currently the directly connected roofs only contribute $5.8 \%$ of the annual runoff from the whole 100 acre $(40.5 \mathrm{ha})$ area, while the much greater area of disconnected roofs contributes $7.2 \%$. The current flow contributions of all roofs in the area total $13 \%$. If all the roofs were directly connected they would contribute $31 \%$ of the total area runoff, and the runoff from the total area would increase by $25 \%$ compared to current conditions, a significant increase. In contrast, if the currently directly connected roofs were disconnected through a downspout disconnection program, the total roof contributions would decrease to $9 \%$, and the total area runoff would decrease by $5 \%$. Since $85 \%$ of the existing roofs in the area are already disconnected, the effects of controlling the remaining directly connected roofs are therefore limited for this area.

Table 8.1 Roof area runoff contributions in Kansas City pilot subwatershed.

\begin{tabular}{|c|c|c|c|c|}
\hline & $\begin{array}{l}\text { Runoff from } \\
\text { the currently } \\
\text { directly con- } \\
\text { nected roofs } \\
\text { of } 1.87 \text { acres }\end{array}$ & $\begin{array}{l}\text { Runoff from } \\
\text { the currently } \\
\text { disconnected } \\
\text { roofs of } 10.57 \\
\text { acres }\end{array}$ & $\begin{array}{l}\text { Land use } \\
\text { total run- } \\
\text { off from } \\
\text { the } 100 \\
\text { acres }\end{array}$ & $\begin{array}{c}R \mathrm{v} \text { (ratio } \\
\text { of runoff } \\
\text { to rain } \\
\text { volume) }\end{array}$ \\
\hline Base conditions $\left(\mathrm{ft}^{3} / \mathrm{y}\right)$ & 257200 & 319200 & 4449000 & 0.3 \\
\hline$\%$ contributions & 5.8 & 7.2 & & \\
\hline$\%$ roof contributions & 13.0 & & & \\
\hline If all roofs connected $\left(\mathrm{ft}^{3} / \mathrm{y}\right)$ & 257200 & 1458000 & 5588000 & 0.38 \\
\hline$\%$ contributions & 4.6 & 26.1 & & \\
\hline$\%$ roof contributions & 30.7 & & & \\
\hline If all roofs disconnected $\left(\mathrm{ft}^{3} / \mathrm{y}\right)$ & 56340 & 319200 & 4248000 & 0.29 \\
\hline$\%$ contributions & 1.3 & 7.5 & & \\
\hline$\%$ roof contributions & 8.8 & & & \\
\hline
\end{tabular}

Table 8.2 shows that directly connected roofs in the study area contribute 4.5 times the amount of runoff per unit area as the disconnected roofs. These 
calculated runoff values and the benefits of the disconnections of the roofs are based on the calibrated hydrology portion of WinSLAMM. These calibrations were initially based on data from a series of ten long term monitoring sites for a variety of land uses conducted in the early 1980s (the USEPA's NURP studies and the Toronto area wastewater management study). These areas ranged from mostly paved directly connected areas to complex residential areas having different soils and pavement and roof hydraulic connections. The calibration process is multi-stepped and was able to quantify these effects for a range of conditions. Pitt (1995) summarizes these data. Since that time, the urban hydrology components of the model have been verified for a number of independent areas, mostly by the USGS in support of the WI stormwater management efforts.

The values in Table 8.2 indicate that $78 \%$ of the annual runoff from the disconnected roofs is infiltrated as it passes over pervious areas on the way to the drainage system for these rains. The flow reduction is less for more intense rains and greater for smaller rains. These data are for a long term 27 year continuous rainfall record, and not for individual design storms that can lead to inaccurate conclusions. These results are highly dependent on local conditions and are not necessarily applicable elsewhere. For this study area, it is much less cost effective to use roof runoff controls for further reducing the runoff from the already disconnected roofs compared to runoff controls for the directly connected roofs. If an infiltration or beneficial use control is used to control runoff from disconnected roofs, they would have to be about 4.5 times larger than if used for runoff control from directly connected roofs in order to have the same benefit on the overall discharge volume from the area. This demonstrates the effects of scaling in the modeling; analyses conducted adjacent to a roof will result in much greater benefits than if the analyses were conducted at the entry point into the stormwater collection system. Another unique element of this Kansas City demonstration project is that monitoring and modeling will be conducted at multiple scales in the study area to very these initial conclusions and quantify the effects of locating the same controls at different locations in an area.

Table 8.2 Runoff from directly connected and disconnected roofs in Kansas City pilot subwatershed.

\begin{tabular}{lccc}
\hline & Area (acre) & Runoff $\left(\mathrm{ft}^{3}\right)$ & $\begin{array}{c}\text { Runoff per area } \\
\left(\mathrm{ft}^{3} / \mathrm{acre} / \mathrm{y}\right)\end{array}$ \\
\hline $\begin{array}{l}\text { Directly connected roof runoff } \\
\text { Disconnected roof runoff }\end{array}$ & 1.87 & 257,200 & 137,500 \\
& 10.57 & 319,200 & 30,200 \\
$\begin{array}{l}\text { Ratio of disconnected to di- } \\
\text { rected connected roof runoff }\end{array}$ & 5.65 & 1.24 & 0.220 \\
\hline
\end{tabular}




\subsubsection{Rain Gardens}

This initial modeling assumed a typical rain garden configuration. This unit rain garden was then used to model the benefits of different roof areas, soils, and numbers of rain gardens in an area. The size of the rain garden assumed is therefore not critical, but it has typical geometry to minimize potential discontinuities during these calculations.

Each unit rain garden has a top surface area of $160 \mathrm{ft}^{2}\left(15 \mathrm{~m}^{2}\right)$, being $10 \mathrm{ft} \times 16 \mathrm{ft}(3 \mathrm{~m} \times 4.9 \mathrm{~m})$. It is excavated to an overall depth of $3 \mathrm{ft}(900$ $\mathrm{mm})$, with $2 \mathrm{ft}(600 \mathrm{~mm})$ backfilled with a loam soil. The top $1 \mathrm{ft}(300 \mathrm{~mm})$ is left open to provide surface storage $9 \mathrm{in}$. $(230 \mathrm{~mm})$ deep. A native soil infiltration rate of $0.2 \mathrm{in} . / \mathrm{h}(5 \mathrm{~mm} / \mathrm{h})$ was used in the basic calculations, while the loam soil fill only had an infiltration rate of $0.15 \mathrm{in} . / \mathrm{h}(3.8 \mathrm{~mm} / \mathrm{h})$. Disturbed urban soils, such as in this area, can have greatly reduced infiltration rates compared to non-compacted soils. As noted, extensive infiltration rate measurements were made throughout the site and the modeling rates were selected based on these measurements, along with later deep core infiltration rate measurements. The only outlet used (besides the natural infiltration) was a surface overflow along one edge of the rain garden. Later calculations examined different soil characteristics and source areas.

The use of one of these unit rain gardens per house results in a rain garden that is $17 \%$ of the surface of the typical roof in the study area. Figure 8.4 summarizes the continuous modeling results for several different sizes and numbers of rain gardens, per house, based on the 1990 rain year, the year that was selected as being representative of the long-term rain record. Disconnected roofs already experience substantial runoff reductions in the study area, even with the low infiltration rates $(78 \%$ runoff reductions associated with disconnected roofs, reflecting the unit area runoff from directly connected roofs of about $137500 \mathrm{ft}^{3} / \mathrm{acre} / \mathrm{y}$ to $30200 \mathrm{ft}^{3} / \mathrm{acre} / \mathrm{y}$ for disconnected roofs). Therefore, as shown on Figure 8.4, a rain garden having about 13\% of the area of a directly connected roof would have to be used to be equivalent to the current benefits of disconnected roof drainage to the adjacent landscaped area. This corresponds to a rain garden having a surface area of $120 \mathrm{ft}^{2} /$ house $\left(11 \mathrm{~m}^{2} /\right.$ house), with the rain garden overflow then flowing directly to the combined sewer drainage system. The total pervious area per house in the study area averages about $4925 \mathrm{ft}^{2}\left(458 \mathrm{~m}^{2}\right)$, although only a relatively small fraction is likely affected by the disconnected roof drains.

A goal of reducing $90 \%$ of the runoff from directly connected roofs in the study area would require rain gardens that are $20 \%$ of the roof areas, or a total area of $200 \mathrm{ft}^{2} /$ house $\left(18 \mathrm{~m}^{2} /\right.$ house). In most cases, this area would be made of two to four separate and smaller rain gardens per house, depending 
on the locations of the roof gutter downspouts. With a peaked roof that drains wholly to one end of the house, two rain gardens each $100 \mathrm{ft}^{2}\left(9.3 \mathrm{~m}^{2}\right)$ would be needed, while for a more common peaked roof that drains to each corner separately, then four separate smaller rain gardens would be needed, each $50 \mathrm{ft}^{2}\left(4.7 \mathrm{~m}^{2}\right)$.

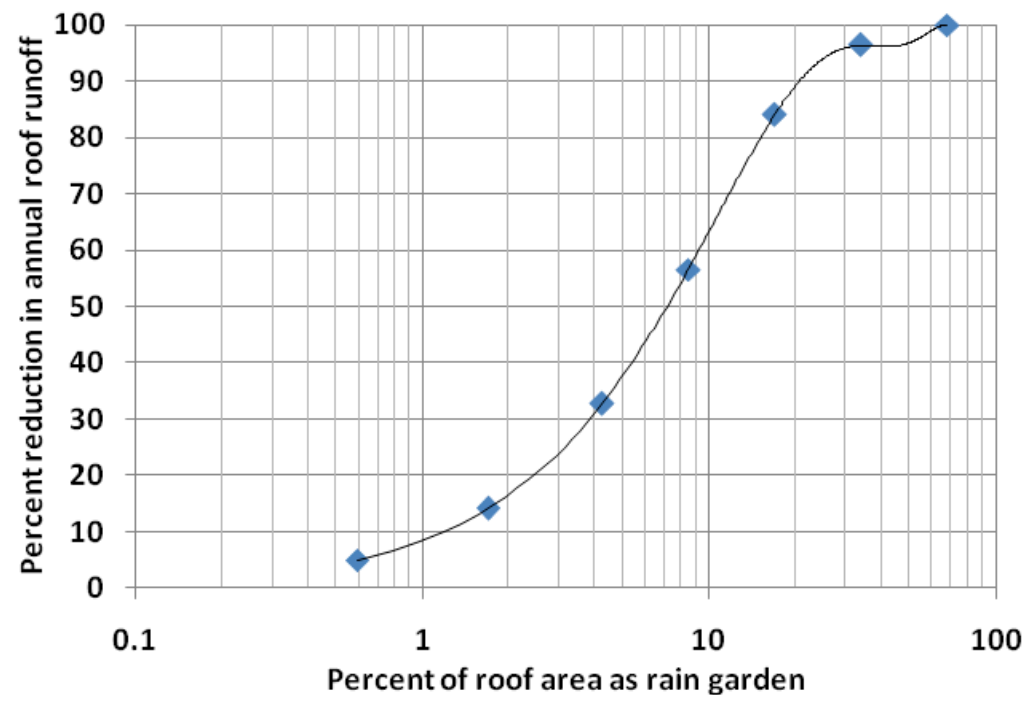

Figure 8.4 Percentage reduction in annual runoff from directly connected roofs with the use of rain gardens.

\subsubsection{Rain Barrels and Water Tanks}

Rain barrels are a very simple method for collecting roof runoff for later uses. In this analysis, irrigation of typical turf grass landscaping around the homes in the study area is the assumed use. This irrigation requirement was described previously and is the additional water needed to supplement the long-term monthly average rainfall in order to match the ET requirements of turf grass for the area. As will be shown in the analysis, small rain barrels provide limited direct benefits, so larger water tanks or cisterns were also considered. In order to be most effective, these calculations assume that the irrigation rates are controlled by soil moisture conditions in order to closely match the ET requirements. This level of control is usually best achieved with a single large storage tank connected to an automatic irrigation system. Numerous smaller rain barrels are obviously more difficult to control and are usually set to drain through a manual valve to a soaker hose or other manual irrigation component. 
For these calculations, each unit rain barrel is assumed to have a 35 gal storage capacity $(130 \mathrm{~L})$. Each roof has an average area $945 \mathrm{ft}^{2}\left(87.8 \mathrm{~m}^{2}\right)$ and receives $3100 \mathrm{ft}^{3}(87800 \mathrm{~L}$ ) rainfall annually. As noted above, this analysis is only for the directly connected roofs in the area, which are $15 \%$ of the total roof area in the pilot subwatershed.

Table 8.3 and Figure 8.5 show the benefits of storage and irrigation use of runoff collected from directly connected roofs. Using a single rain barrel per house is expected to provide $24 \%$ reduction in runoff through irrigation to match ET when evaluated using the long-term continuous model. However, more than 25 of these small rain barrels per house would be needed to reduce the roof's contributions by $90 \%$, an extreme number that would never be used in practice. This number of small rain barrels corresponds to a total storage quantity of about $1.4 \mathrm{in}$. $(36 \mathrm{~mm})$ over the roof area.

Table 8.3 Benefits of storage and irrigation use of roof runoff at Kansas City pilot subwatershed.

\begin{tabular}{ccccc}
\hline $\begin{array}{c}\text { Number of rain } \\
\text { 35 gal rain } \\
\text { barrels/house }\end{array}$ & $\begin{array}{c}\text { Rain barrel stor- } \\
\text { age/house }\left(\mathrm{ft}^{3}\right) \text { per } \\
\text { roof area }\left(\mathrm{ft}^{2}, \text { or } \mathrm{ft}\right. \\
\text { depth over the roof) }\end{array}$ & $\begin{array}{c}\text { Total annual roof } \\
\text { runoff for 86 houses } \\
\left(\mathrm{ft}^{3}\right)\end{array}$ & $\begin{array}{c}\text { Total annual } \\
\text { roof run- } \\
\text { off/house }\left(\mathrm{ft}^{3}\right)\end{array}$ & $\begin{array}{c}\text { Reduction in } \\
\text { roof runoff } \\
(\%)\end{array}$ \\
\hline 0 & 0 & 257200 & 2990 & 0 \\
1 & 0.0050 & 196700 & 2290 & 24 \\
2 & 0.010 & 181400 & 2110 & 29 \\
4 & 0.020 & 155800 & 1810 & 39 \\
10 & 0.050 & 112400 & 1310 & 56 \\
25 & 0.12 & 67200 & 780 & 74 \\
100 & 0.50 & 3160 & 37 & 99 \\
\hline
\end{tabular}

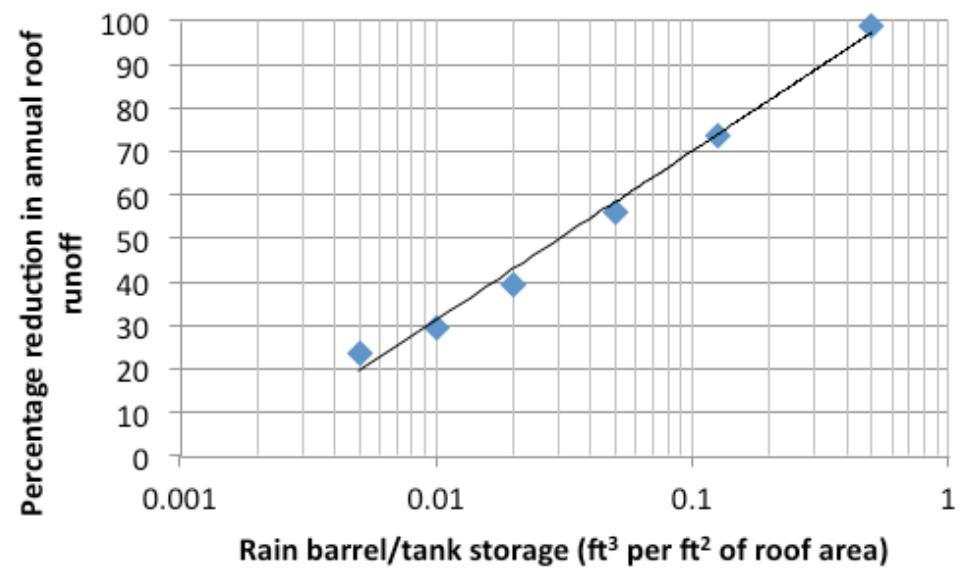

Figure 8.5 Reduction of annual runoff from directly connected roofs with the use of runoff storage and irrigation. 
As the storage volume increases, it obviously becomes impractical to meet the total storage volume with small rain barrels. Table 8.4 shows the equivalent size of larger water tanks or cisterns when the number of rain barrels is greater than four. As an example, a moderately-sized water tank $5 \mathrm{ft}$ $(1.5 \mathrm{~m})$ diameter and $6 \mathrm{ft}(1.8 \mathrm{~m})$ tall has a similar storage capacity to 25 small rain barrels, and if the tank diameter was increased to $10 \mathrm{ft}(3.3 \mathrm{~m})$ in diameter, this larger tank would have a capacity similar to 100 rain barrels.

Table 8.4 Roof runoff storage options.

\begin{tabular}{cccc}
\hline $\begin{array}{c}\text { Runoff storage per } \\
\text { house }\left(\mathrm{ft}^{3}\right)\end{array}$ & $\begin{array}{c}\text { Number of } 35 \text { gal rain } \\
\text { barrels }\end{array}$ & $\begin{array}{c}\text { Height for } 5 \mathrm{ft} \\
\text { diameter tank }(\mathrm{ft})\end{array}$ & $\begin{array}{c}\text { Height for } 10 \mathrm{ft} \\
\text { diameter tank }(\mathrm{ft})\end{array}$ \\
\hline 0 & 0 & 0 & 0 \\
4.7 & 1 & 0.24 & 0.060 \\
9.4 & 2 & 0.45 & 0.12 \\
19 & 4 & 0.96 & 0.24 \\
47 & 10 & 2.4 & 0.60 \\
118 & 25 & 6.0 & 1.5 \\
470 & 100 & 24 & 6.0 \\
\hline
\end{tabular}

The use of a small tank, at least $5 \mathrm{ft}(1.5 \mathrm{~m})$ diameter and $6 \mathrm{ft}(1.8 \mathrm{~m})$ tall, is the recommended amount of storage for the currently directly connected roofs in the study area. This would provide a $74 \%$ reduction in the total annual runoff discharges.

\subsubsection{Combinations of Rain Gardens and Rain Barrels}

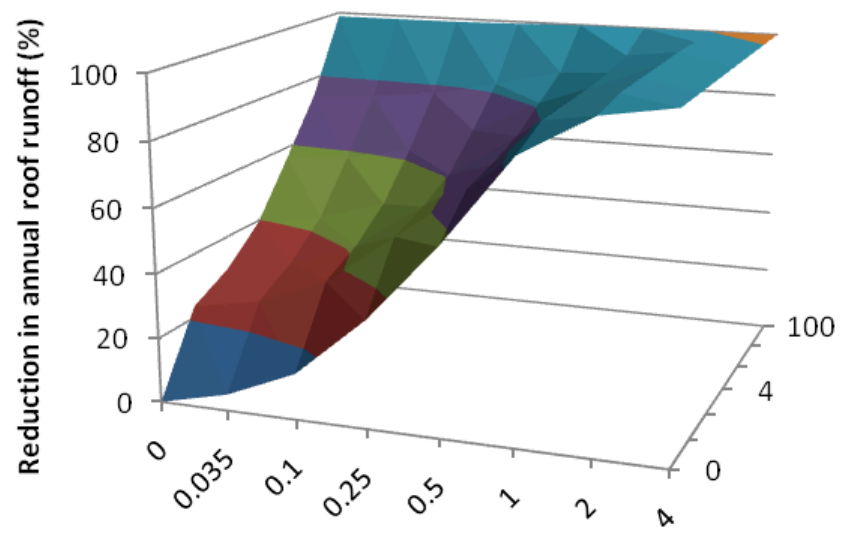

\section{\# of rain gardens per house}

Figure 8.6 Reduction in annual runoff from directly connected roofs with the use of $160 \mathrm{ft}^{2}\left(15 \mathrm{~m}^{2}\right)$ rain gardens and $35 \mathrm{gal}(130 \mathrm{~L})$ rain barrels for roof runoff storage and irrigation. 
It may be most efficient to use rain barrels and rain gardens together at the houses that have directly connected roofs. Figure 8.6 shows the reductions in the annual runoff for the range of these controls that have been previously examined separately. In order to obtain a reduction of $90 \%$ in the total annual runoff, it will be necessary to have more than one rain garden/house, unless the number of rain barrels is more than 24 /house. In that case, the size of the rain gardens can be reduced to $80 \mathrm{ft}^{2} /$ house $(7.4$ $\mathrm{m}^{2} /$ house) or less. This area for the rain gardens can be divided into multiple rain gardens with smaller units near each roof drain downspout. The rain barrels are each $35 \mathrm{gal}(130 \mathrm{~L})$ and the total volume associated with multiple rain barrels can be combined when using a larger water tank.

\subsubsection{Roof Drain Downspout Disconnections}

Another option for the control of runoff from directly connected roofs is to disconnect the roof drain downspouts that are currently directed towards pavement which is, in turn, directly connected to the drainage system. When disconnecting downspouts, the water needs to be redirected over pervious ground, most commonly regular turf grass. Based on previous site monitoring and model calibration efforts, referenced above, this is most effective for small residential roofs if the water is discharged to relatively flat lawns in good condition that have flow path lengths $\geq 10 \mathrm{ft}(3.0 \mathrm{~m})$. In the study area, the soils have poor infiltration characteristics, but the amount of water that can be infiltrated is still relatively high, mostly because the roofs only constitute $12 \%$ of the lot area and the landscaped areas account for $65 \%$ of the total area. The available flow paths are therefore relatively long $(25 \mathrm{ft}$ to 50 $\mathrm{ft}, 7.6 \mathrm{~m}$ to $15 \mathrm{~m}$ ), increasing the infiltration potential.

WinSLAMM version 9.5 was used to make a preliminary analysis of the effects of disconnecting the directly connected roofs to allow the runoff to flow across the pervious areas, based on the long-term monitoring of paired watersheds having both connected and disconnected roofs. Version 10 will be able to more directly calculate these effects using site characteristics for the actual overland flow paths. When additional site details are incorporated, the enhanced model will re-perform the calculations. However, these results can be roughly compared to the previous results associated with rain gardens and rain barrels. Disconnecting roofs in areas having clay soils is expected to result in $78 \%$ annual runoff reductions, as previously shown. Similar analyses (not shown) found that these same site characteristics, but with silt soils or sandy soils, increase these reductions to $87 \%$ and $95 \%$ respectively. Obviously, these reductions refer to the roof runoff contributions only, not to the runoff from the complete site. 
The volumetric runoff coefficient $R v$, the ratio of runoff volume to rainfall volume falling on an area, increases with increasing rain depths. For directly connected pitched roofs, the $R v$ is about 0.7 for 0.1 in. $(2.5 \mathrm{~mm})$ rains, and is quite close to 1.0 for rains larger than about 2 in. $(50.8 \mathrm{~mm})$. When disconnected from clayey soils, runoff is not expected until the rain depth $>0.1$ in. $(2.5 \mathrm{~mm})$ and the $R v$ starts to climb steeply with rains $>2$ in. $(50 \mathrm{~mm}) . R v$ is expected to be very large for very large and unusual rains that can cause severe flooding, whether the roofs are disconnected or not. However, the effects of roof disconnections for small and intermediate rains are large. Figure 8.7 illustrates the percentage reductions associated with disconnecting the directly connected roofs for three main soil categories (the pilot subwatershed has mostly marginal clay to silt soils).

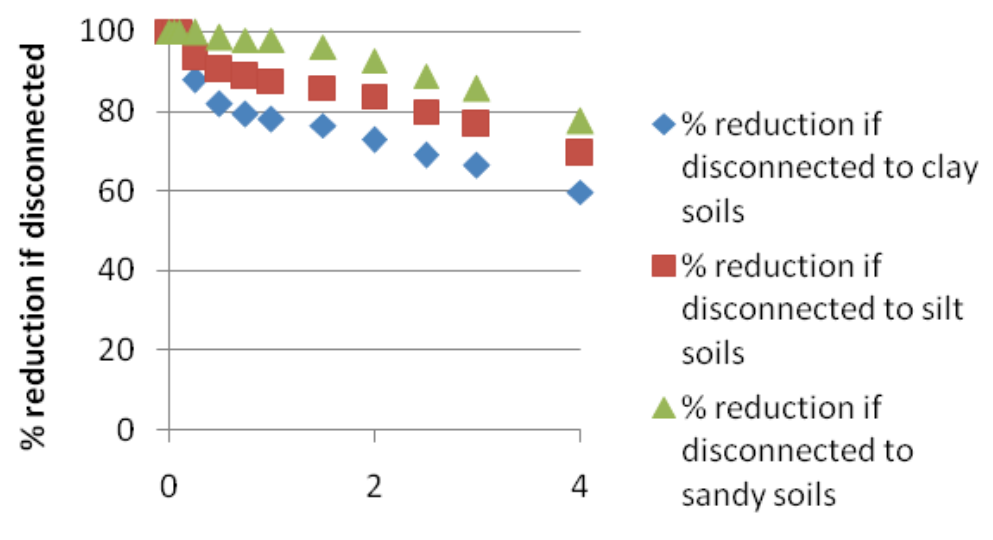

Rain depth (inches)

Figure 8.7 Runoff reductions when directly connected roofs are disconnected.

\subsection{Preliminary Evaluations of Curb Cut Biofilters}

The final designs of the curb cut and curb extension biofilters are still being completed, but a preliminary analysis of simple curb cut rain gardens was conducted using WinSLAMM. A prior paper in this conference series (Pitt et al., 2008) described the detailed computational processes that WinSLAMM uses for biofilter evaluations, along with many of the soil and plant properties that were used in these analyses. Figure 8.8 is an excerpt from the $65 \%$ plans for one of the street sections in the study area. The modeled curb cut unit biofilters are assumed to be simple excavations $20 \mathrm{ft}(6.1 \mathrm{~m})$ long and $5 \mathrm{ft}(1.5 \mathrm{~m})$ wide, located in the terrace between the sidewalk and the street. 
Their surface depth was limited to $1 \mathrm{ft}(0.3 \mathrm{~m})$ to decrease uneven steep slopes and other hazardous conditions. It is assumed that the subsoil would be loosened after the excavation and a minimum amount of organic material would be added to the soil. There are about $6 \mathrm{mi}(10 \mathrm{~km})$ of streetside drainage systems in the 100 acre ( 40.5 ha) test watershed. Therefore, a maximum of 1500 rain gardens was assumed to be possible in the area. However, a more reasonable maximum number would be 750 due to the presence of large trees and other interferences.

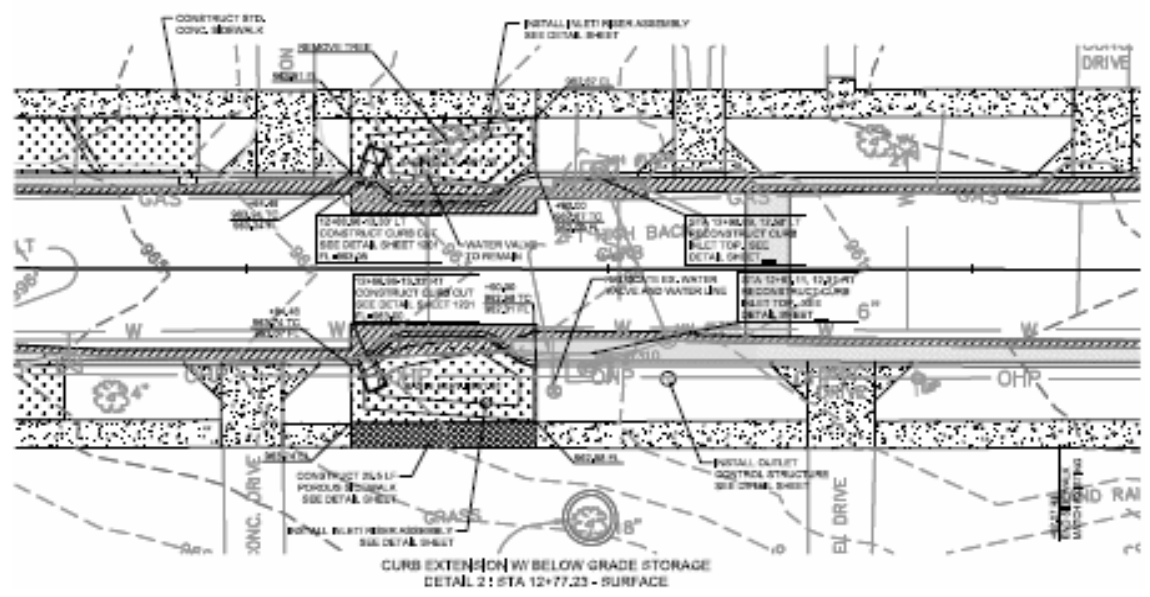

Figure 8.8 Example excerpt from $65 \%$ plans prepared by URS for project streets. Construction will occur in spring and summer of 2011.

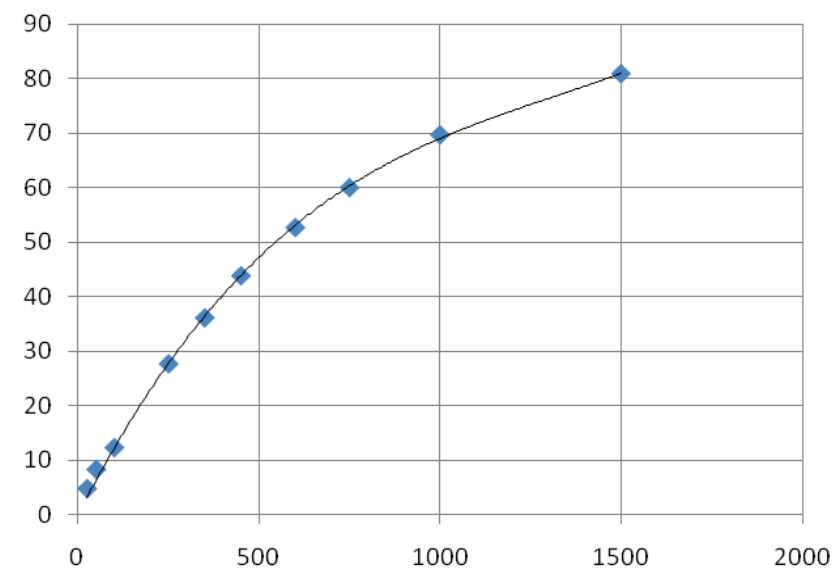

Figure 8.9 Annual runoff volume reduction (\%) for typical rain year (1990) for different numbers of simple curbcut rain gardens per 100 acre watershed. 
Figure 8.9 is a plot of the percentage of the typical annual runoff amount that can be infiltrated by the curbcut rain gardens, based on the number of units used, and with no other controls in the area. With a maximum 1500 units possible, up to $80 \%$ of the annual runoff may be infiltrated. With 400 units, $40 \%$ of the annual flows would be diverted from the combined sewers.

\subsection{Conclusions}

A detailed land survey, based on procedures described by Bochis et al. (2009), found that most of the homes in the test watershed already have disconnected roofs ( $85 \%$ of all roof areas), and that the total roof areas account for $13 \%$ of the total study area. This means it will be difficult to detect any total area benefits of controls implemented for the directly connected roofs, as they are expected to contribute only small portions of the total site runoff. The land survey also found that $65 \%$ of the area is landscaped, with most being turf grass in poor to good condition. This information was used in conjunction with regional ET data to calculate the amount of supplemental irrigation needed to meet the ET requirements of typical turf grass, considering the longterm rainfall patterns. Most of the supplemental irrigation would be needed during the months of July and August, while excess rainfall occurs in October through December (compared to ET requirements during these relatively dormant months). Soil infiltration monitoring in the area, along with recent soil profile surveys, has indicated relatively poor deep subsurface draining soil in the test area. Surface infiltration rates during several hour rains may be about $0.5 \mathrm{in} . / \mathrm{h}(13 \mathrm{~mm} / \mathrm{h})$, or greater, but the rate decreases with increasing rain depths. For conservative modeling calculations, deep soil infiltration rates of $0.2 \mathrm{in} . / \mathrm{h}(5 \mathrm{~mm} / \mathrm{h}$ were used.

The expected major sources of runoff from the test area vary for different rain depth categories. Directly connected impervious areas are the major runoff sources only for rains $<0.25 \mathrm{in}$. $(6.3 \mathrm{~mm})$ The large landscaped areas contribute $50 \%$ of the runoff for rains larger than $0.5 \mathrm{in}$. $(12.7 \mathrm{~mm})$ The directly connected roofs, which make up only $2 \%$ of the study area, contribute $6 \%$ of the total annual flows. The disconnected roofs, which make up $11 \%$ of the area, contribute $7 \%$ of the total flows. Thus, complete control of the runoff from the directly connected roofs would only reduce the total area runoff by a very small amount, less than can be reliably detected by monitoring the total runoff from the area. However, the source area monitoring that will be conducted at selected directly connected roofs is expected to result in information that can be used to more accurately predict these runoff reductions in other areas. 
The modeling calculations illustrate the different effects of using rain gardens, rain barrels or tanks, or simple disconnections of the directly connected roofs. The results are presented on the basis of the effects for the directly connected roofs alone; if calculated for the whole drainage area, the contribution would be $<5 \%$. If all the roofs were directly connected, they would then contribute $30 \%$ of the annual flows, and the outfall consequences for the whole area from these roof controls would be substantially larger.

Performance plots were prepared comparing the size of the rain gardens to the size of the roof vs percent flow reductions. Rain gardens that are sized to be about $20 \%$ of the roof area are expected to result in $90 \%$ reductions of total annual flow compared to directly connected roofs, even in this area of relatively poor soil. This area is $200 \mathrm{ft}^{2} /$ house $\left(19 \mathrm{~m}^{2} /\right.$ house $)$ which could, for example, be made up of several smaller rain gardens each located at a downspout. Reductions of $50 \%$ in the total annual flows could be obtained if the total rain garden area per house was $7 \%$ of the roof area.

Rain barrel effectiveness is related to the need for supplemental irrigation and how that matches the rains for each season. The continuous simulations used a typical 1 y rain series and average monthly ET values for varying amounts of roof runoff storage. A single 35 gal $(130 \mathrm{~L})$ rain barrel is expected to reduce the total annual runoff by about $24 \%$ from the directly connected roofs, if the water use can be closely regulated to match the irrigation requirements. If four rain barrels were used (such as one on each corner of a house and receiving runoff from separate roof downspouts), the total annual volume reductions could be as high as $40 \%$. Larger storage quantities result in increased usage, but likely require larger water tanks. Water use from a single water tank is also easier to control through soil moisture sensors and can be integrated with landscaping irrigation systems for almost automatic operation. A small tank $5 \mathrm{ft}(1.5 \mathrm{~m})$ diameter and $6 \mathrm{ft}(1.8 \mathrm{~m})$ high is expected to result in $75 \%$ total annual runoff reductions, while a larger 10 $\mathrm{ft}(3 \mathrm{~m})$ diameter tank $6 \mathrm{ft}(1.8 \mathrm{~m})$ tall would approach complete roof runoff control.

The use of rain barrels and rain gardens together at a home is more effective than using either method alone: the rain barrels would overflow into the rain gardens, so their irrigation use is not quite as critical. In order to obtain reductions of $90 \%$ in the total annual runoff, it is necessary to have at least 1 rain garden/house, unless more than one $5 \mathrm{ft}(1.5 \mathrm{~m})$ water tank/house is also used. In that case, the rain gardens can be reduced to $80 \mathrm{ft}^{2} /$ house $(7.4$ $\mathrm{m}^{2} /$ house).

Simple disconnections of the currently directly connected roofs can provide significant reductions in the annual flows from the roofs for expected less cost. A reduction of $80 \%$ is expected in the total flows from the directly 
connected roofs, with disconnections, even with the site's clay soils, with most runoff flow reductions occurring during small rains, and the reductions decreasing as the rains increase in depth. This flow volume reduction is enhanced by the relatively small roof areas and large landscaped areas which provide long flow paths. With steep slopes and poor grass, this reduction will be less.

The best combination of control options is not necessarily obvious. The CSO program must meet permit requirements which specify certain amounts of upland storage in the watershed. Other elements, including costs, aesthetics, improvements to streetside infrastructure, and other potential benefits, also need to be considered in a decision analysis framework. Caution is needed when comparing the amount of site runoff storage provided by these upland controls to the total storage goals to meet the objective of the CSO control program (288 000 gal, 1090000 L). As an example, storage provided at directly connected roofs needs to be enlarged by a factor of 1.3 to 1.4 compared to curb side biofilters because not all of the storage is available during all rains. In addition, their drainage is influenced by low infiltration rates through the native soils, compared to flow controls directly connected to the combined sewers. Basically, the curbcut biofilters have access to almost all of the flows in the area, so their storage volumes are more effectively utilized. More significantly, if storage was provided at roofs that are already disconnected, their storage volumes would need to be discounted by a factor of 4.5 when compared to the total site storage goals, due to the existing infiltration already occurring from the disconnected roofs.

As noted earlier, these are preliminary analyses that were used to direct design elements of the stormwater program in the study area. As monitoring data become available the models will be verified, and as final designs become available these analyses will be re-evaluated. Obviously, these findings are not expected to be applicable to other areas, based on the specific site characteristics (small homes, poor soils, roofs mostly disconnected). The purpose of this chapter is to illustrate how a continuous model can be used to quantify the interaction of different controls in an area, to illustrate some of the scaling issues associated with placement of controls at different locations, and to describe this major demonstration project.

\section{Acknowledgment}

The National Risk Management Research Laboratory of the USEPA's Office of Research and Development has funded this research element in support of the Aging Water Infrastructure Research Program of its Water Supply and Water Resources Division. 


\section{References}

Bochis, C., R.E. Pitt and P. Johnson. 2008. "Land Development Characteristics in Jefferson County, Alabama." Journal of Water Management Modeling R228-16. doi: 10.14796/JWMM.R228-16.

Pitt, R.E. 1999. "Small Storm Hydrology and Why it is Important for the Design of Stormwater Control Practices." Journal of Water Management Modeling R204-04. doi: 10.14796/JWMM.R204-04.

Pitt, R.E. and J. Voorhees. 2007. "Using Decision Analyses to Select an Urban Runoff Control Program." Journal of Water Management Modeling R227-04. doi: 10.14796/JWMM.R227-04.

Pitt, R., S.-E. Chen, S.E. Clark, J. Lantrip and C.K. Ong. 2008a. "Compaction's impacts on urban stormwater infiltration." Journal of Irrigation and Drainage Engineering. Vol. 134, no. 5, pp. 652-658.

Pitt, R. and S.E. Clark. 2008b. "Integrated stormwater management for watershed sustainability." Journal of Irrigation and Drainage Engineering. Vol. 134, no. 5, pp. 548-555.

Pitt, R.E., S. Clark, P. Johnson and J. Voorhees. 2008. "Evapotranspiration and Related Calculations for Bioretention Devices." Journal of Water Management Modeling R228-19. doi: 10.14796/JWMM.R228-19.

Selbig, W.R., and N. Balster, 2010, Evaluation of turf-grass and prairie-vegetated rain gardens in a clay and sand soil, Madison, Wisconsin, water years 2004-08: U.S. Geological Survey Scientific Investigations Report 2010-5077, 72 p.

Struck, S.D. 2009. "Green infrastructure for CSO control in Kansas City, Missouri." 2009 Water Environment Federation Technical Exposition and Conference, Orlando, FL, October $11-14,2009$. Conference CD. 